\title{
Growth and survival of the pearl oyster Pteria hirundo (L.,1758) in an intermediate stage of culture in Santa Catarina, Brazil
}

\author{
Albuquerque, MCP. ${ }^{a *}$, Alves, $R^{b}$, Zanandrea, $A C V^{b}$, \\ Ferreira, JF. ${ }^{a}$, Melo, CMR. ${ }^{a}$ and Magalhães, ARM. ${ }^{b}$ \\ áLaboratório de Moluscos Marinhos, Universidade Federal de Santa Catarina - UFSC, \\ Servidão dos Coroas, s/n, Barra da Lagoa, CEP 88061-600, Florianópolis, SC, Brazil \\ bNúcleo de Estudos em Patologia Aquícola, Centro de Ciências Agrárias - CCA, \\ Universidade Federal de Santa Catarina - UFSC, \\ Rod. Admar Gonzaga, 1346, Itacorubi, CEP 88034-001, Florianópolis, SC, Brazil \\ *e-mail: mcpa73@gmail.com
}

Received December 6, 2010 - Accepted January 12, 2011 - Distributed February 29, 2012

(With 2 figures)

\begin{abstract}
There are no records in Brazil for the culture of Pteridae family oysters, genus Pteria and Pinctada. The intermediate culture can be considered one of the critical stages during the oyster farming. The changes in life conditions from a semi-closed environment provided by the collector to the structures utilized for the growth represents a considerable stress factor to which the animals are subjected. The goal of the present study was to evaluate the growth and survival of the pearl oyster Pteria hirundo (Linnaeus, 1758) kept in intermediate lanterns. Seeds of $P$. hirundo, obtained through larviculture carried out at the Marine Molluscs Laboratory (UFSC), southern Brazil were detached from the collectors, transferred and kept in an intermediate culture system (oyster lantern). During 6 months, growth (dorsoventral height - DVH in $\mathrm{mm}$ ) and survival (\%) were evaluated. Two size classes were tested: medium (M), between 3.4 and $4.4 \mathrm{~mm}$, and large (L), bigger than $4.5 \mathrm{~mm}$. The density of occupation in each floor of the lantern was 50\%. At the end of the experiment, the survivals observed were 90 and $94 \%$ for the sizes $\mathrm{M}$ and L, respectively. Medium juveniles of Pteria hirundo had an average (Std) increase of $16.1( \pm 4.38) \mathrm{mm}$ in the dorso-ventral height, and large juveniles an average increase of $11.4( \pm 3.77) \mathrm{mm}$ after six months of experiment. The results observed during the intermediate stage of cultivation indicate that Pteria hirundo presents survival and growth similar to other species of pearl oysters traditionally used in the pearl industry in several countries.
\end{abstract}

Keywords: pearl oysters, growth, survival, intermediate culture, Pteria hirundo.

\section{Crescimento e sobrevivência da ostra perlífera Pteria hirundo (L., 1758) em cultivo intermediário em Santa Catarina, Brasil}

\begin{abstract}
Resumo
No Brasil, não há registro de cultivos para ostras da família Pteridae, gêneros Pteria e Pinctada. O cultivo intermediário pode ser considerado um dos estágios críticos no processo de cultivo, pois a mudança nas condições de vida de um ambiente semifechado oferecido pelo coletor de sementes para as estruturas intermediárias utilizadas para criar os animais representa um fator de estresse considerável ao qual estes são submetidos. Este trabalho teve como objetivo avaliar o crescimento e a sobrevivência de ostras perlíferas Pteria hirundo (Linnaeus, 1758) mantidas em lanternas intermediárias. Sementes de P. hirundo, obtidas em larvicultura realizada no Laboratório de Moluscos Marinhos da Universidade Federal de Santa Catarina (UFSC), sul do Brasil, foram destacadas dos coletores, transferidas e mantidas em sistema intermediário de cultivo, Durante seis meses, foram avaliados o crescimento (altura dorso ventral - DVH - em mm) e a sobrevivência (\%). Foram avaliadas duas classes de tamanho: média (M) - entre 3,4 e 4,4 mm, e grande (G) - maior que 4,5 mm. A densidade de ocupação de cada andar da lanterna foi de $50 \%$ da área superficial do andar. Ao final do período avaliado, a sobrevivência dos indivíduos da classe M foi $90 \%$ e, para a classe G, foi $94 \%$. Animais M de $P$. hirundo tiveram um crescimento médio (desvio padrão) de $16,1 \mathrm{~mm}( \pm 4,38)$ de altura dorso ventral e os animais $\mathrm{G}$ apresentaram um aumento médio de $11,4 \mathrm{~mm}( \pm 3,77)$. Os resultados observados, durante a etapa de cultivo intermediário, indicam que Pteria hirundo apresenta sobrevivência e crescimento semelhantes a outras espécies de ostras perlíferas, tradicionalmente utilizadas na indústria de pérolas em diversos países.
\end{abstract}

Palavras-chave: ostra perlífera, crescimento, sobrevivência, cultivo intermediário, Pteria hirundo. 


\section{Introduction}

Several species of edible molluscs that occur on the Brazilian coast can be exploited as a means of offering new options of monetary investment and alternate culture sites. However, it is better to initiate the diversification with known species that have shown good growth performance and market potential elsewhere. Considering the potential of organisms belonging to the Pteridae family-as has been demonstrated in other countries (FAO, 1991)including the capacity to generate dividends along with touristic activities (Williams et al., 2000), the Marine Molluscs Laboratory (LMM) is initiating research for the production in laboratory and growth-out of the pearl oyster Pteria hirundo (Linnaeus, 1758) aiming for the implementation of farming of this species.

The species Pteria hirundo (Linnaeus, 1758) is a bivalve belonging to the Pteridae family (Rios, 2009), also found in the literature with the synonyms Pteria colymbus (Rödinger, 1798) and Pteria atlantica (Lamarck, 1819) (Abbott, 1974). Despite the large number of studies on the culture of pearl oyster worldwide, in Latin America, knowledge of basic parameters is still deficient and fragmented in the literature.

In Mexico, there are several studies with Pteria sterna (Gould, 1851) and Pinctada mazatlantica (Hanley, 1846) (Monteforte and Cariño, 1992; Monteforte et al., 1994; Monteforte and Garcýa-Gasca, 1994; Monteforte and Wright, 1994; Monteforte, et al., 1995; Monteforte et al., 1996; Monteforte and Morales-Mulia, 2000). Pinctada imbricata (Roding, 1758) is studied in Venezuela, Colombia (Borrero, 1994; Pico et al., 1999), and Australia (O'Connor and Lawler, 2004), showing good culture potential. In Brazil, there are no records of culture of oysters from the Pteridae family, genus Pteria and Pinctada.

According to Fassler (1995), 32 nations are in some stage of pearl culture, ranging from pilot-scale research to commercial production. The biggest pearl producers are in Japan, China, South Pacific and Southeast Asia.

The species Pinctada maxima is cultivated commercially in Australia, Indonesia, Malaysia, Myanmar, and the Philippines; the Pinctada margaritifera (Linnaeus, 1758) in the French Polynesia, Cook Islands, and in some islands in the Central Pacific; the Pinctada martensi (Dunker, 1857) in Japan and China; the Pinctada fucata (Gould, 1850) in India; the Pteria penguin (Roding, 1798) in Japan and Thailand and the Pteria sterna in Mexico (Fassler 1991, 1994, 1995).

With regard to size of the pterids, the oysters Pinctada mazatlanica and Pteria sterna are species of medium to large size (15 to $22 \mathrm{~cm}$ ). The giant Pinctada maxima, found in Northern Australia, the Malaysian sea and the Philippines, can reach $30 \mathrm{~cm}$ of shell diameter as an adult. The species Pteria penguin, found in the Center-Oriental coast and Southeast Asia, reaches $22 \mathrm{~cm}$ of shell height, and Pinctada margaritifera from the French Polynesia is of a similar size to the size of $P$. mazatlanica. The smaller species represent the majority of the species from the
Pteridae family and rarely grow over $8 \mathrm{~cm}$, such as the Pinctada imbricata (Indo-Pacific), the Pinctada martensi (Japan), the Pteria hirundo (Mediterranean) and the Pteria colymbus (Roding, 1798) (Caribbean) (Shirai 1994; Monteforte, 1996).

The selection method for culture of bivalves varies according to the site condition, differences of culture among species (Gaytan-Mondragon et al., 1993), economics (Rahma and Newkirk, 1987), and practical considerations (Crawford et al., 1988).

The criteria utilised to evaluate if the culture method is favourable to juveniles depend on site conditions, such as composition and abundance of predators and the quantity of fouling (Southgate and Beer, 2000).

Handling, predation, stock density and colonisation of associated species are some factors that affect the growth and survival of young pearl oysters during the early stages of cultivation (Gervis and Sims, 1992; Monteforte et al., 1994, 1996; Taylor et al., 1998).

The main goal of the present study was to evaluate the growth and survival of the pearl oyster Pteria hirundo during the intermediate stage of culture.

\section{Material and Methods}

Seeds of the pearl oyster Pteria hirundo were obtained in larviculture carried out at the Marine Molluscs Laboratory (LMM) - Federal University of Santa Catarina (UFSC). After the larviculture phase, the seeds were detached from the collectors, transferred, and kept - in a nursery (oyster lantern) at the culture site in the sea, located at Ponta do Sambaqui beach in Florianópolis, Santa Catarina, Brazil.

For six months, mean (Std) growth was evaluated monthly in 30 specimens randomly, considering for this the dorso-ventral height in mm (Jiuan-Jiuan and Okutani, 2003). Survival was also evaluated, reported as a percentage. Initially, two size classes were tested: medium (M), between 3.4 and $4.4 \mathrm{~mm}$, and large (L), bigger than $4.5 \mathrm{~mm}$. The density of occupation in each level of the lantern was $50 \%$. Dead seeds were taken from the lanterns monthly.

The handling of Pteria hirundo during the experiment was carried out with the seeds always immersed in sea water from the experimental site $(200 \mathrm{~L}$ tanks) in order to avoid stress.

Because there is not a culture method designed for pearl oysters in Santa Catarina State, Brazil, the usual methodology for the culture of juveniles of the Japanese oyster, Crassotrea gigas, was utilized.

\subsection{Statistical analysis}

The difference between the average growth of the animals of the class $\mathrm{M}$ and $\mathrm{L}$, over the months was evaluated by analysis of variance. Comparing the angles of the lines fitted to the data with variance analysis, considering $\mathrm{M}$ and $\mathrm{L}$ as fixed treatments with co-variable in linear terms, and the interactions treatment vs. time (age) .

Survival at the end of the experiment was analysed using a comparison test among proportions. Analyses were performed using the SAS software package. 
Table 1. Growth in height $(\mathrm{mm})$ and survival as percentage for two classes of size (M and L) of the pearl oyster Pteria hirundo.

\begin{tabular}{|c|c|c|c|c|}
\hline \multirow[t]{2}{*}{ Time/month } & \multicolumn{2}{|c|}{$\begin{array}{l}\text { Media }(\text { Std) } \\
\text { Height }(\mathbf{m m})\end{array}$} & \multicolumn{2}{|c|}{ Survival (\%) } \\
\hline & $\mathbf{M}$ & $\mathbf{L}$ & $\mathbf{M}$ & $\mathbf{L}$ \\
\hline 0 & $39.40( \pm 2.17)$ & $45.30( \pm 4.98)$ & 100 & 100 \\
\hline 1 & $42.00( \pm 7.54)$ & $45.30( \pm 3.87)$ & 99 & 100 \\
\hline 2 & $43.83( \pm 3.53)$ & $46.10( \pm 1.47)$ & 99 & 100 \\
\hline 3 & $45.50( \pm 4.68)$ & $48.10( \pm 2.88)$ & 99 & 100 \\
\hline 4 & $46.70( \pm 3.56)$ & $50.33( \pm 2.02)$ & 90 & 94 \\
\hline 5 & $51.00( \pm 4.79)$ & $50.90( \pm 5.03)$ & 90 & 94 \\
\hline 6 & $55.50( \pm 4.40)$ & $56.70( \pm 6.15)$ & 90 & 94 \\
\hline
\end{tabular}

\section{Results}

The size class medium (M) had an initial number of organisms of 319 and for the size class large (L) it was 100. At the end of the experiment, after six months, 287 and 94 individuals for the sizes $\mathrm{M}$ and $\mathrm{L}$, respectively, were obtained. These data are expressed as percentage of survival in Table 1.

Medium juveniles (M) of Pteria hirundo, between 3.4 and $4.4 \mathrm{~mm}$, had an increase of $16.1( \pm 4.38) \mathrm{mm}$ in the dorso-ventral height, and large juveniles (L), bigger than $4.5 \mathrm{~mm}$, had an increase of $11.4( \pm 3.77) \mathrm{mm}$ after six months of the experiment (Table 1).

It was not possible to find statistical differences, at 5\% between the final percentage of survival for size classes $M$ and $\mathrm{L}$, considering the animals that started the experiment.

It was possible to detect difference between the average growth of animals and in the first month of cultivation $(\mathrm{P}<0.01)$. However, there was no significant difference between the growth in the fifth and sixth months of cultivation $(\mathrm{P}>0.01)$. Comparing the angle between the straight lines fitted to the data (Figure 1) it was possible to detect significant difference between them $(\mathrm{P}<0.001)$ with the angle of Class $\mathrm{M}$ greater than that of Class L, a fact which leads to the absence of difference when we analysed the size of the two classes of animals after six months of cultivation.

The water temperature at the experimental site reached the highest values during the summer months, between December and March, and started to fall in May with the proximity of the winter, up to the month of July, when the experiment was ended (Figure 2).

\section{Discussion}

The nursery can be considered a critical stage during the cultivation of Pinctada mazatlantica. The changes in life conditions from a semi-closed environment provided by the collector to the "exposed" cages or tanks utilized for the growth of the seeds represent a considerable stress factor to which the juveniles are subjected (Monteforte and Garcia-Gasca, 1994).

In commercial farming of oysters from the genus Pinctada, the nursery is not a distinct stage. Normally the seeds are kept in the collectors for about 6 months and

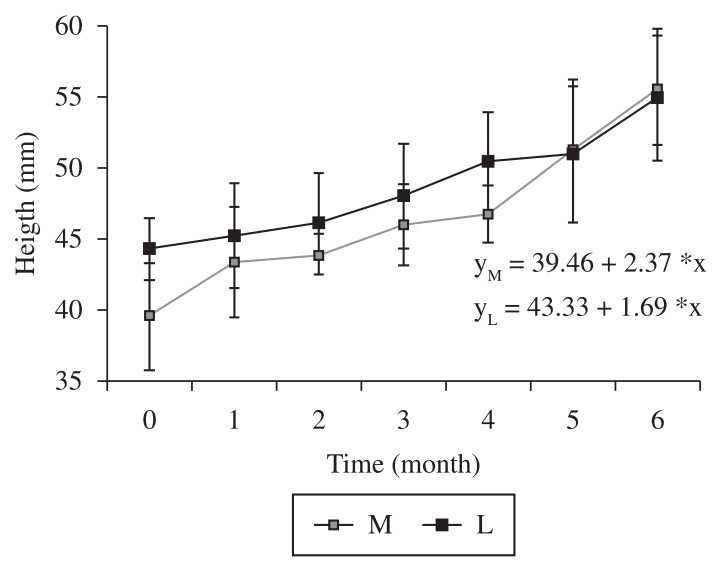

Figure 1. Growth representation in height for the two size classes (M and L) of Pteria hirundo during the experimental period.

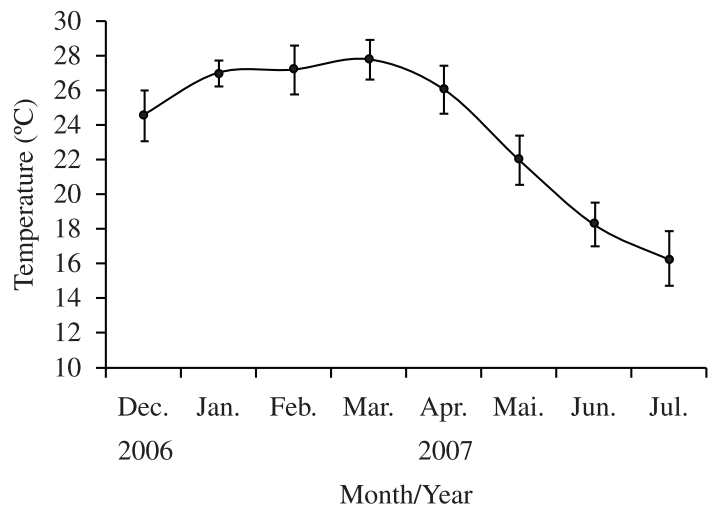

Figure 2. Average monthly temperature with respective deviations for the sea water at the experimental site.

afterwards are transferred and placed in different types of cages where they stay up to the moment to induce the production of pearl (Wada, 1973; Coeroli et al., 1984; Gervis and Sims, 1992).

The survival of seeds of Pinctada mazatlantica is affected by stress factors such as detachment of the byssus, cleaning of the shells, and air exposure (Taylor et al., 1997). The small seeds of pearl oysters are more vulnerable, as 
shown by Monteforte and Morales-Mulia (2000), whom also recommend a careful handling, with a frequency of 2 months, in order to avoid damage to the byssus. They also pointed out the necessity to further study the stock density and cleaning effects on P. mazatlantica.

However, for Pinctada mazatlantica, as well as for Pteria sterna, preliminary studies indicated that the collectors should be recovered not later than 3 months after immersion, otherwise high seed mortality can occur as a result of predation and competition among associated species (Monteforte and Garcia-Gasca, 1994; Monteforte and Wright, 1994; Monteforte et al., 1995; Wright, 1997).

In the present study it was observed that this species presents gregarious behaviour, fixing among themselves with the byssus, but it was not observed fixation on the nursery lantern.

While big pearl oysters, like Pinctada mazatlantica, do not show gregarious behaviour (Monteforte and Cariño, 1992), such behaviour is quite common among smaller oysters like P. martensi, P. fucata (Chellam et al., 1983; Chellam, 1987; Wada, 1991; Gervis and Sims, 1992) and P. radiata (Salvat and Rives, 1980), as well as with Caribbean species such as Pinctada imbricata and Pteria colymbus (Borrero, 1994; Lodeiros et al., 1999).

Friedman and Southgate (1999) observed that juveniles of $P$. margaritifera attached to the plastic mesh in the tray showed a significantly higher growth rate when compared to seeds that grew loosely during the nursery stage.

Culture methods that limit the physical contact among juveniles, such as bags and ear hanging, prevent grouping and allow uniform growth (Southgate and Beer, 2000).

After 6 months of evaluation, the survival observed in juveniles of Pteria hirundo was 90 and $94 \%$ for medium and large individuals, respectively. These results are similar to those obtained by other researchers that worked with pearl oysters. Changes in survival were observed from the third evaluation onwards (Table 1), and can be attributed to a decrease in the water temperature in that same period (Figure 2). For both size classes, there was no significant difference in the final survival. Exogenous factors (such as temperature and salinity) influence the metabolism of bivalve molluscs, since they are ectotermic animals and have an open circulatory system. An effort to produce and maintain germinative tissue, associated to a stress factor (changes in temperature or salinity) during an age where there is also a great energy demand for growth can lead to mortality.

For laboratory-produced juveniles of $P$. margaritifera, Southgate and Beer (2000) observed 100\% survival, but this value can vary with juvenile size and culture method. A survival between 68 and $88 \%$ was reported for juveniles of $P$. margaritifera with 3 to 5 months of age and initial height of 9.8 to $13.9 \mathrm{~mm}$ cultivated for 19 weeks in baskets and nursery lanterns (Southgate and Beer, 1997).

Juveniles of this species with 6 to 12 months of age cultured in the French Polynesia had mortality of approximately 30\% (Coeroli et al., 1984). Friedman and Southgate (1999) reported an average survival of $86.9 \%$ for juveniles of $P$. margaritifera (24-33 mm of dorsoventral height DVH) cultivated in the Salomon Island for 3 months in nursery lanterns.

A possible explanation for the faster growth observed in the $M$ class would be that these seeds would not be sexually mature presenting preferential somatically growth, while those in the L class allocate energy for reproduction (gametogenic growth) reducing the somatic growth rhythm and making the growth in this latter class less evident. In a similar way, the low growth observed for both classes during the 2 last months of evaluation, less than $2 \mathrm{~cm}$, (Table 1) could be explained by an energy investment in reproductive tissues.

Regarding the growth, it is possible to observe that in the fifth month of the experiment there was an equalisation of the two size classes. The growth observed during this life stage of pearl oysters is less intense than that observed for the early life stages of this species. According to Grotta and Lunetta (1980), the lower somatic growth in later stages could be related to higher energy expenditure by females in the production of ovocytes and in the syntheses of yolk, and by the males in the production of sperm.

Lodeiros et al. (1999) evaluated during 10 months the growth of juveniles of Pteria colymbus with initial size of $13.5 \mathrm{~mm}$ height. These authors reported a fast growth rate during the first five months, followed by lower rates during the final months of experiment.

Southgate and Beer (1997), working with laboratoryproduced seeds in Australia, observed that juveniles of $P$. margaritifera grew on average $40.5 \mathrm{~mm}$ and average weight of $7.4 \mathrm{~g}$ after 7 months of culture.

Coeroli et al. (1984) observed that seeds of $P$. margaritifera collected in the wild and cultured in suspended system in the French Polynesia had a DVH growth of 8 to $10 \mathrm{~mm}$ after 3 months, and $40-50 \mathrm{~mm}$ after 6 months of culture.

After settling, the oyster Pinctada imbricate grows around $7 \mathrm{~cm}$ in 14 months (León et al., 1987).

Alagarswami et al. (1989) observed that seeds of P. margaritifera, produced in the laboratory and cultivated in "pearl nets" at $5 \mathrm{~m}$ depth had a daily growth rate of $0.4 \mathrm{~mm}$ of dorso-ventral height.

In the Salomon Islands, Friedman e Southgate (1999) reported for juveniles of $P$. margaritifera with a dorso-ventral height of 8.3-51.5 mm an increase of size of 20.4-24.8 mm within 3 months and of 30.7-36.5 mm within 5 months.

The species from the genus Pteria has a significant economical value and great culture potential, as it has been demonstrated in countries where the pearl culture is established. They can become a new option of organism for farming in the current sites and mariculture conditions in Santa Catarina State. However, first it is necessary to develop the technology required to cultivate this species. In this manner, it is possible to exploit the potential of culture of Pteria in Brazil.

Acknowledgements - The authors would like to thank $\mathrm{CNPq}$ for financial support and CAPES for the Doctoral scholarship during the realization of this study. 


\section{References}

ABBOTT, RT., 1974. American Seashells. 2nd ed. New York: van Nostrand Reinhold Co. 663 p.

ALAGARSWAMI, K., DHARMARAJ, S., CHELLAM, A. and VELAYUDHAN, TS., 1989. Larval and juvenile rearing of blacklip pearl oyster Pinctada margaritifera (Linnaeus). Aquaculture, vol. 76, p. 43-56. http://dx.doi.org/10.1016/0044-8486(89)90250-0

AQUACOP, 1982. French Polynesia-Country report. In Proceedings from a workshop held in Singapore, 1982. Ottawa: International Development Research Centre. p. 31-33.

BARBER, BJ. and BLAKE, NJ., 1991. Reproductive physiology. In SHUMWAY, SE. Scallop: biology, ecology and aquaculture. Amsterdam: Elsevier.

BORRERO, J., 1994. Potential for pearl culture in Colombia, Abstracts, Pearls '94 International Conference, Honolulu, USA. Journal Shellfish Research, vol. 1, no. 13, p. 331-332.

CHELLAM, A., 1987. Biology of pearl oyster. In ALAGARSWAMI, K. Pearl Culture. Cochin: Bulletin of the Central Marine Fisheries Research Institute. p. 13-29.

CHELLAM, A., VELAYUDHAN, TS., DHARMARAJ, S., VICTOR, ACC. and GANDHI, AD., 1983. A note on the predation on pearl oyster Pinctada fucata (Gould) by some gastropods. Indian Journal Fish, vol. 30, p. 337-339.

COEROLI, M., DE GAILLAND, D., LANDRETT, JP. and COATANEA, D. 1984. Recent inovation in cultivation of molluscs in French Polinesia. Aquaculture, vol. 39, p. 45-67. http://dx.doi. org/10.1016/0044-8486(84)90258-8

CRAWFORD, CM., LUCAS, JS. and NASH, WJ., 1988. Growth and survival during the ocean-nursery rearing of giant clams, Tridacna gigas: 1. Assessment of four culture methods. Aquaculture, vol. 68, p. 103-113. http://dx.doi.org/10.1016/00448486(88)90234-7

Food and Agriculture Organization of the United Nations FAO, 1991. Pearl oyster farming and pearl culture. Rome: FAO. $68 \mathrm{p}$.

FASSLER, RC., 1991. Farming jewels: The aquaculture of pearls. Aquaculture Magazine, p. 34-52.

FASSLER, RC., 1994. Abstracts of papers presented at Pearls .94, International Pearl Conference, Honolulu, Hawaii, May 14-19, Journal Shellfish Research, vol. 13, no. 1, p. 325-354.

FASSLER, RC., 1995. Farming jewels, new developments in pearl farming. World Aquaculture, vol. 26, no. 3, p. 5-10.

FRIEDMAN, KJ. and SOUTHGATE, PC., 1999. Growout of blacklip pearl oyster, Pinctada margaritifera collected as wild spat in Solomon Islands. Journal Shellfish Research, vol. 181, p. $159-167$

GAYTAN-MONDRAGON, IG., CACERES-MARTINEZ, C. and TOBIAS-SANCHEZ, M., 1993. Growth of the pearl oysters Pinctada mazatlanica and Pteria sterna in different culture structures at La Paz Bay, Baja California Sur, Mexico. Journal World Aquaculture Soc., vol. 24, p. 541-549.

GERVIS, MH. and SIMS, NA., 1992. The biology and culture of pearl oysters (Bivalvia: Pteriidae). London: ODA. vol. 21, 49 p. ICLARM Studies Review.
GROTTA, M. and LUNETTA, JE., 1980. Ciclo sexual de Anomalocardia brasiliana (Gmelin, 1791) do litoral do Estado da Paraíba. Revista Nordestina de Biologia, vol. 3, no. 1, p. 5-55.

JIUAN-JIUAN, H. and OKUTANI, T., 2003.Taxonomy and Distribution of the Genera Pteria and Pinctada (Bivalvia: Pteriidae) in Taiwan. Journal of Fisheries Society of Taiwan, vol. 30, no. 3, p. 199-216.

LEÓN, L., CABRERA, T. and TROCCOLI, L., 1987. Fijacion e indice de engorde de la ostra perla Pinctada imbricata, Roding 1798 (Mollusca:Bivalvia) en tres bancos naturales del nororientede Venezuela. Porlamar: Centro de Investigaciones Cientificas, Universidad de Oriente. 20 p. Contribuições Científicas, n. 12.

LODEIROS, CJ., RENGER, JJ. and HIMMELMAN, JH. 1999. Growth of Pteria colymbus (Roding, 1798)in suspended culture in Golfo de Cariaco, Venezuela. Journal Shellfish Research, vol. 18, p. 155-158.

MONTEFORTE, M., 1996. Cultivo de Ostras Perleras y Perlicultura. In CASAS-VALDEZ, M. and PONCE-DÍAZ, G. Estudio del Potencial Pesquero y Acuícola de Baja California Sur. La Paz: Instituto Nacional de la Pesca.

MONTEFORTE, M., ALDANA, C., BERVERA, H., PEREZ V., RAMÝREZ JJ., SAUCEDO, P. and WRIGHT H., 1996. Effects of biofouling on growth and survival of pearl oysters Pteria sterna and Pinctada mazatlanica during nursery culture at station El Merito, Bahýa de La Paz, South Baja California Mexico. In Proceedings of the Annual Meeting of the World Aquaculture Society - WAS 96 , 1996. Bangkok, Thailand. p. 258-259.

MONTEFORTE, M. and CARIÑO, M., 1992. Exploration and evaluation of natural stocks of pearl oysters Pinctada mazatlanica and Pteria sterna (Bivalvia, Pteriidae): La Paz Bay, South Baja California, Mexico. AMBIO, Journal of the Human Environment, vol. 21, p. 314-320.

MONTEFORTE, M., BERVERA, H. and MORALES, S., 1994. Growth and survival of pearl oysters Pinctada mazatlanica and Pteria sterna in extensive conditons at Bahý $a$ de La Paz, South Baja California, Mexico. Journal of Shellfish Research, vol. 13, no. 1, p. 344-345.

MONTEFORTE, M. and GARCÝA-GASCA, A., 1994. Spat collection studies of pearl oysters Pinctada mazatlanica and Pteria sterna (Bivalvia: Pteriidae) in Bay of La Paz, South Baja California, Mexico. Hydrobiologia vol. 291, no. 3, p. 21-34. http://dx.doi.org/10.1007/BF00024236

MONTEFORTE, M. and MORALES-MULIA, S., 2000. Growth and survival of the Califia mother-of-pearl oyster Pinctada mazatlanica (Hanley 1856) under different sequences of nursery culture-late culture at Bahýa de La Paz, Baja California Sur, México. Aquaculture Research, vol. 31, p. 901-915. http://dx.doi. org/10.1046/j.1365-2109.2000.00501.x

MONTEFORTE, M. and WRIGHT, H.,1994. Ecology of pearl oyster spat collection in Bahýa de La Paz, South Baja California, Mexico: temporal and vertical distribution, substrate selection, associated species. Journal of Shellfish Research, vol. 13, no. 1, p. 342-343.

MONTEFORTE, ME., KAPPELMAN, E. and ESPINOZA, BE., 1995. Spatfall annual survey of pearl oyster Pteria sterna (Gould) on experimental collectors at Bahý $\neg$ a de La Paz, South Baja California, Mexico. Aquaculture and Fisheries Management, vol. 26, p. 497-511. 
O'CONNOR, WA. and LAWLER, NF. 2004. Reproductive condition of the pearl oyster, Pinctada imbricata, Ro ding, in Port Stephens, New South Wales, Australia Aquaculture Research, vol. 35 , p. 385-396.

PICO, D., NUÑEZ, M., NARVÁEZ, N. and LODEIROS, C., 1999. Crecimiento de la ostra perlý fera Pintada imbricata Ro"ding, 1798 en condiciones de cultivo suspendido y de fondo en el Golfo de Cariaco, Venezuela. In Anais do II Congreso Suraméricano de Acuicultura, 1999. Pto. La Cruz, Venezuela. p. 115.

RAHMA, IH. and NEWKIRK, GF., 1987. Economics of tray culture of the mother-of-pearl shell Pinctada margaritifera in the Red Sea, Sudan. Jounal World Aquaculture Society, vol. 18, no. 3 , p. 156.

RIOS, EC., 2009. Compendium of Brazilian Sea Shells. Rio Grande: Fundação Cidade do Rio Grande, EVANGRAF Ed. 668 p.

SALVAT, B. and RIVES, C., 1980. Les Coquillages de Polynesie. Papeete: Editions du Pacifique. 392 p.

SASTRY, AN., 1975. Physiology and ecology of reproduction in marine invertebrates. In VERNBERG, FJ. Physiological ecology of estaurine organisms. Columbia: University of South Carolina Press. p. 279-299.

SHIRAI, S., 1994. An overview of pearl oyster culture in the world. Conferencia magistral. In Anais do Congreso Internacional Pearls, 1994. Honolulu, Hawaii.

SOUTHGATE, PC. and BEER, AC., 1997. Hatchery and early nursery culture of black lip pearl oyster (Pinctada margaritifera L.). Journal of Shellfish Research, vol. 16, no. 2, p. 561-567.
SOUTHGATE, PC. and BEER, AC., 2000. Growth of blacklip pearl oyster Pinctada margaritifera juveniles using different nurseryculture techniques Aquaculture, vol. 187, p. 97-104. http:// dx.doi.org/10.1016/S0044-8486(99)00392-0

TAYLOR, JJ., SOUTHGATE, PC. and ROSE, RA., 1997. Fouling animals and their effect on the growth of silver-lip pearl oysters, Pinctada maxima (Jameson) in suspended culture. Aquaculture, vol. 153, p. 31-40. http://dx.doi.org/10.1016/S0044-8486(97)00014-8

TAYLOR, JJ., SOUTHGATE, PC. and ROSE, RA., 1998. Effects of mesh covers on growth and survival of silver-lip pearl oyster (Pinctada maxima, Jameson) spat. Aquaculture, vol. 153, p. 41-49.

WADA, K., 1973. Modern and traditional methods of pearl culture. Underwater Journal, vol. 5, no. 1, p. 28-33.

WADA, KT., 1991. The pearl oyster, Pinctada fucata G Family Pteriidae. In MENZEL, W. Estuarine and marine bivalve mollusc culture. Boston: CRC Press. p. 246-260.

WILLIAMS, MJ., BELL, JD., GUPTA, MV., DEY, M., AHMED, M., PREIN, M., CHILD, S., GARDINER, PR., BRUMMETT, R. and JAMU, D., 2000. Responsible aquaculture can aid food problems. Nature, vol. 406, p. 673.

WRIGHT, H., 1997. Ecologýa de la captacion de semilla de madreperla Pinctada mazatlanica y concha nacar. Pteria Sterna (Bivalvia: Pteriidae), en la Isla Gaviota, Bahýa de LaPaz, B.C.S., Mexico. La Paz: Centro Interdisciplinario de Ciencias Marinas, Instituto Politécnico Nacional. 139 p. Dissertação de Mestrado 